\title{
UNIVERSITYOF
}

FORWARD

THINKING

WESTMINSTER用

WestminsterResearch

http://www.westminster.ac.uk/westminsterresearch

Gossip in organisations: Contexts, consequences and

controversies

Michelson, G., van Iverson, A. and Waddington, $\mathrm{K}$.

This is a copy of the accepted author manuscript of the following article: Michelson, G., van Iverson, A. and Waddington, K. 2010. Gossip in organisations: Contexts, consequences and controversies. Group \& Organization Management. 35 (4), pp. 371 390. . The final definitive version is available from the publisher Sage at:

https://dx.doi.org/10.1177/1059601109360389

(C) The Author(s) 2010

The WestminsterResearch online digital archive at the University of Westminster aims to make the research output of the University available to a wider audience. Copyright and Moral Rights remain with the authors and/or copyright owners.

Whilst further distribution of specific materials from within this archive is forbidden, you may freely distribute the URL of WestminsterResearch: ((http://westminsterresearch.wmin.ac.uk/)).

In case of abuse or copyright appearing without permission e-mail repository@westminster.ac.uk 


\section{Gossip in Organizations: Contexts, Consequences and Controversies}

Michelson, G., van Iterson, A. \& Waddington, K. (2010). Group \&

Organization Management. 35(4), 371-390

Grant Michelson

Audencia Nantes School of Management

Ad van Iterson

Maastricht University

Kathryn Waddington

City University London

This article examines the key themes surrounding gossip including its contexts, the various outcomes (positive and negative) of gossip as well as a selection of challenges and controversies. The challenges which are highlighted revolve around definitional issues, methodological approaches, and ethical considerations. Our analysis suggests that the characteristics and features of gossip lend itself to a process-oriented approach whereby the beginning and, particularly, end points of gossip are not always easily identified. Gossip about a subject or person can temporarily disappear only for it to re-surface at some later stage. In addition, questions pertaining to the effects of gossip and ethical-based arguments depend on the nature of the relationships within the gossip triad (gossiper, listener/respondent and target).

Keywords: gossip; organizations; process orientation; methodology; ethics.

Gossip is a ubiquitous yet seemingly ephemeral type of informal talk, and much of what is currently known about gossip is diffused across social history, communication studies, anthropology, psychology and sociology. Gossip has received attention in relation to its role for 
RUNNING HEAD: Michelson, van Iterson, Waddington / Gossip in Organizations

individuals and for groups, including issues of social comparison, identity and reputation (e.g. Dunbar, 1996; 2004, Emler, 1994; Gluckman 1963, Wert \& Salovey, 2004). In addition to its diffusion across different disciplinary areas, gossip also connects well with extant theoretical perspectives. For example, social exchange theory, attribution theory, cognitive dissonance, uncertainty reduction theory and established-outsiders theory (Berger, 2005; Elias \& Scotson, 1994; Festinger, 1957; Heider, 1958) can all be invoked to explain why and how individuals might engage in gossip and deal with internal conflict about participating in gossip.

It is apparent that gossip is an important area of interdisciplinary scholarship and yet within organization and management sciences there is a general dearth of studies into the phenomenon. To date, gossip has predominantly featured within the organizational and management literature as either: (i) coincidental to the mainstream disciplines and domains, materializing as a by-product (and even waste product) of inquiry into, for example, organizational culture, storytelling and conflict (e.g. Gabriel, 1991, 1995; Kolb \& Putnam, 1992); or (ii) in the 'popular management' literature, where the common assumption is that gossip is detrimental to work morale and productivity, is not to be encouraged or condoned, and therefore is a problem to be 'managed' (e.g. Baker \& Jones, 1996; Therrien, 2004). The popular management perspective to some extent exemplifies a view of gossip associated with negative, pejorative and trivial assumptions, sometimes seen as 'women's talk', inauthentic discourse, to be discouraged or banned (Emler, 1994; Jones, 1980).

In contrast to these two positions, there are some important contributions within management scholarship which contend a different perspective. Noon and Delbridge (1993) proposed that gossip was intrinsic to organizational life and called for systematic research into gossip in organizations, while Kurland and Pelled (2000) developed a conceptual model of gossip and power. In addition, van Iterson and Clegg (2008) demonstrated how gossip can operate at the organizational level (and not merely at the individual or group levels). In a 
RUNNING HEAD: Michelson, van Iterson, Waddington / Gossip in Organizations

similar vein, the purpose of this article - and Special Issue more generally - is to provide more clarity and direction to what remains an under-researched organizational topic.

The article adopts a process orientation whereby we examine the principal contextual and motivational factors, as well as the main consequences of gossip. Such an orientation would permit, we argue, some flexibility in what is regarded (or not regarded) as gossip by organizational members (see Mills, this volume), and how gossip manifests itself in different organizations. Thus, while cross-sectional studies can have their advantages, they might also have some limitations with regard to identifying the beginning and end points of gossip in terms of its effects on individuals and groups. Gossip about a subject or person can temporarily disappear only for it to 're-surface' at the group or organizational level at some later stage. This call for flexibility does not suggest that definitional and methodological rigor for example, is reduced in importance; rather, it is to better consider how gossip actually operates and evolves over time. To assist in this task we discuss some general challenges and controversies which surround gossip. One such theme is the perspective of ethics whereby the consequences of gossip for individuals, groups and organizations can depend on whether we are referring to one or more participants in the gossip triad-gossiper, listener/respondent and the target of gossip.

\section{CONTEXTS OF GOSSIP}

This section examines briefly the general contexts of gossip as an aspect of informal interpersonal communication in organizations. It seeks to locate itself within the scope of such questions as: who gossips to whom, about what, how and why, and explores when and where gossip might occur? Gossip is a type of storytelling discourse that exists in the 'unmanaged spaces' of organizations, and is a form of emergent story (Boje, 1991; Gabriel, 1995; 2000). It 
RUNNING HEAD: Michelson, van Iterson, Waddington / Gossip in Organizations

is a way of talking - and by talking we mean written or spoken texts - that enables the communication of emotions, opinions, beliefs and attitudes about the experience of work and organizational life. As such, gossip is usually expressed in small trusted groups, which reinforces power differentials and insider/outsider group dynamics (e.g. Elias \& Scotson, 1994; Gluckman, 1963; Hannerz, 1967; Kniffin \& Wilson, this volume; Kurland \& Pelled, 2000; Soeters \& van Iterson, 2002; Suls, 1977). Gossip in organizations also plays a role in the maintenance of relationships within and between individuals and groups, and there are expectations and informal protocols that influence who gossips to whom, and about what subject (e.g. Fox, 2001; Nicholson, 2000, 2001). The particular situation, shared understandings, and interpersonal trust are pertinent here in order for gossip to occur as an 'accepted' exchange of information. Social and group norms influence the extent to which gossip is either acknowledged as a type of organizational communication, or is vilified as stigmatized talk.

Moving to the individual level of analysis, gossip can be seen as an activity that is attention seeking, promoting self-interest and self-image through social comparison and the discrediting of others (e.g. Ben-Ze'ev, 1994; Paine; 1967; Suls, 1977). On this basis, it is not surprising that gossip has been identified in studies which explore sexuality and sexual activity in organizations (see King, Reilly \& Hebl, 2008, p. 580; Pierce, Byrne \& Aguinis, 1996, p. 23).

Rumor research suggests that rumors (a related type of communication), which are transmitted through gossip, are more likely to occur when anxious individuals find themselves in conditions of environmental ambiguity (e.g. DiFonzo \& Bordia, 2007; Rosnow, Esposito \& Gibney, 1988). Situations of organizational change are often used to illustrate how such environmental uncertainty shapes the frequency and nature of both rumor (Bordia, Jones, 
RUNNING HEAD: Michelson, van Iterson, Waddington / Gossip in Organizations

Gallois, Callan, \& DiFonzo, 2006) and gossip (Tebbutt \& Marchington, 1997). Rumor and gossip are inter-related, yet conceptually different as illustrated by the following metaphor:

[Rumors] are speculations that arise to fill knowledge gaps or discrepancies. This function differentiates rumor from gossip, which is meant primarily to entertain or convey mores. Gossip is a tasty hors d'oeuvre savoured at a cocktail party; rumor is a morsel hungrily eaten amid an information famine (DiFonzo, Bordia \& Rosnow, 1994, p. 52).

Additionally, it is suggested that rumors are motivated by a desire for meaning, and sensemaking, while gossip seems to be motivated primarily by ego and individual status needs (McAndrew \& Milenkovic, 2002; McAndrew, Bell \& Garcia, 2007; Rosnow \& Fine, 1976). Thus, in the case of gossip in organizations, McClelland's (1987) motivational needs theory (needs for achievement, authority/power and affiliation) provides a further example of how extant theory may permeate the study of gossip.

In order to integrate potentially disparate disciplinary and theoretical perspectives, we contend that it is not necessarily helpful to consider gossip as either a commodity (individual level) or as a system of control (group level). It can be both. Nor is it helpful to position gossip solely as an aspect of organizational communication at the micro level of interpersonal and inter-group relationships. Jones, Watson, Gardner and Gallois (2004, p. 730) note the challenge for researchers to take account of macro level issues relating to the organization as a whole and its relationship to its external environment. The consequences of failing to do so have been empirically demonstrated by van Iterson and Clegg (2008). There is a need then to consider gossip as a process of negotiated interaction between individuals and groups, as well as the effects of gossip in relation to wider organizational issues such as culture, power, identity, and firm reputation. It is to the consequences of gossip that we now turn. 
RUNNING HEAD: Michelson, van Iterson, Waddington / Gossip in Organizations

\section{CONSEQUENCES OF GOSSIP}

This section discusses the organizational consequences of gossip including the impact on networks, the organizational 'grapevine' and avenues for managerial intervention. It is important to acknowledge that the outcomes could be positive or negative, as well as intended and unintended (Michelson \& Mouly, 2004, p. 198). Such a range of possibilities are also noted by Doyle in the following statement: '[Gossip] allows employees to understand and predict their bosses' behaviour; it can be used to ruin competitors' reputations; and the casual context encourages the development of social networks between workmates' (Doyle, 2000, p. 8).

There are a number of ways in which gossip can bring significant benefits to individuals, groups and organizations. One of the major functions of gossip is its ability to provide context-relevant information (Rosnow, 1977). Seen in this way, the acquisition of information via gossip might be one way through which individuals relieve feelings of tension and anxiety especially during periods of organizational change. In turn, this circulation of information can reinforce the social bonds among the participants (Noon \& Delbridge, 1993) as well as serving to communicate and enforce group norms (Kniffin \& Wilson, 2005). Gossip therefore helps shape and re-shape meaning and enables cultural and organizational learning (Baumeister, Zhang \& Vohs, 2004; Kurland \& Pelled, 2000). It has also been demonstrated that gossip can give 'voice' and power to otherwise marginalized individuals in organizations. Ogasawara (1998), for example, showed how women clerical workers in Japan were able to exercise some power over their male managers by virtue of their ability to influence the reputations of these managers through their gossip. Reputation was regarded as important by the managers because it had an impact on their future promotion prospects. 
RUNNING HEAD: Michelson, van Iterson, Waddington / Gossip in Organizations

This last illustration is insightful in that it reveals something about the anticipated reaction of many managers towards organizational gossip. Indeed, much of the 'popular management' literature on gossip in organizations is based upon assumptions that gossip is detrimental to work productivity, and creates a climate of mistrust, innuendo and poor morale (e.g. Akande \& Funmilayo, 1994; Baker \& Jones, 1996; Burke \& Wise, 2003). The case of managers in Japan by Ogaswara (1998) also shows how gossip can threaten managerial power as they seem unable to control the frequency and content of their employees' gossip. To fear gossip in this way has some justification as it can damage organizations (see van Iterson \& Clegg, 2008). However, this is not to suggest that managers only consider the negative consequences of gossip as gossip might also be employed by current organizational elites or those already in powerful positions (and not simply weaker organizational members) (Ayim, 1994, p. 99). There can be benefits of gossip from a management perspective. Information may be more rapidly transmitted to employees than through formal channels and managers can determine the early effects of new programs and practices by gauging reactions to them (Mishra, 1990). This idea suggests that tapping into employee gossip networks can potentially serve as an 'early warning system' to organizations interested in knowing about internal situations and events that might need attention.

Jaeger, Skleder \& Rosnow (1998) used communication network methods in research into the characteristics of gossipers and the people about whom they gossip, and social network models and approaches are seen as pertinent to the development of theory and research into organizational gossip (Brass, Galaskiewicz, Greve \& Tsai, 2004; Foster, 2004). Such network-based analyses can provide sophisticated and detailed accounts of gossip and their effects in organizations, as Grosser, Lopez-Kidwell \& Labianca (this volume) cogently demonstrate. 
RUNNING HEAD: Michelson, van Iterson, Waddington / Gossip in Organizations

Different types of formal and informal communication systems evolve and exist within and between organizations, including clique and personal networks, professional, interprofessional, and virtual networks. With few exceptions, however, network theory and research has largely ignored gossip as a topic worthy of detailed empirical attention. One reason suggested for this omission is that the involvement of active third parties creates 'enormous complexity' for theoretical analysis (Burt \& Knez, 1996, p. 72). However, complexity is not necessarily a valid reason for ignoring a potentially important aspect of this type of networked organizational communication. Nevertheless, 'the grapevine' has emerged as a particular type of communication network through which gossip flows (Davis, 1953a, $1953 \mathrm{~b} ; 1969 ; 1973)$, yet subsequent literature relating to the grapevine and its management is largely unsubstantiated by systematic research (e.g. Karathanos \& Auriemmo 1999; Mishra, 1990). The grapevine is undocumented (unless subject to research), unstructured, but is often perceived as 'the only way to find out what's happening' (Zamanou \& Glaser, 1994).

Cognizance of informal networks, which are supported and sustained by gossip, is a source of power based upon exchange of information and support, enabling managers to: (i) identify where coalitions are located across different organizational spaces, (ii) anticipate resistance to change; or (iii) identify and access support for action or change. Baumeister, Zhang \& Vohs (2004) have argued that managers who are left out of gossip networks - by choice or through the actions of others - have considerably less power and control than those inside the networks, and often do not stay at the top for long.

Drawing from French and Raven's well-known bases of power framework developed in the 1950s, Kurland and Pelled (2000) developed a model of gossip and power (subsequently revised by Noon, 2001) that identifies specific predictions relating to the linkages between positive and negative gossip and the gossiper's coercive, reward, expert and referent power over gossip respondents. Their model also predicts that the effects of gossip on 
RUNNING HEAD: Michelson, van Iterson, Waddington / Gossip in Organizations

different types of power will be moderated by gossip credibility, quality of interpersonal relationship, and organizational culture. This model reflects a precise, yet arguably narrow conceptual framework that fails to embrace a processual perspective on power-gossip. Further, it seems dislocated from accounting clearly for the temporal and spatial dimensions of gossip in organizations. We now turn to a selection of challenges and controversies that organizational and management scholars might encounter in this field. These issues are raised in order to better inform and guide further research.

\section{CONTROVERSIES OF GOSSIP}

There are a number of major challenges and controversies which surround the study of gossip in organizations. We select those issues we believe are the ones that most require attention. These can be summarized as including: (i) the contested problem of definition; (ii) methodological issues; and (iii) ethical and moral considerations. All articles in this Special Issue discuss point (i). However, there is some variation in how gossip has been defined and measured across these studies. The second and third points have seldom been examined as important themes in the literature in their own right.

\section{Definitional Issues}

Popular definitions of gossip have tended to result in a problem of demarcation for researchers. Such common conceptions imply informal chat, easy or unconstrained talk about people or social incidents. However, these popular definitions are unsatisfactory and inappropriate for research purposes because they fail to address a wider range of perspectives and contexts. As we have already contended, gossip is frequently associated with pejorative 
RUNNING HEAD: Michelson, van Iterson, Waddington / Gossip in Organizations

assumptions and negative evaluations, but, as Foster (2004) points out, most researchers who claim to study gossip also include positive and neutral evaluations under their topic matter. In social and organizational science terms, the definition of gossip is also problematic because of the multiplicity of theoretical underpinnings, which perceive gossip differently, with 'different authors within each discipline rarely agreeing on what gossip is' (Noon \& Delbridge, 1993, p. 23). This is further compounded by gossip's relationship to a number of other communicative and conversational phenomena, such as chatting, rumor, storytelling and urban legends (Guerin \& Miyazaki, 2006). Table 1 is indicative of the range of underpinning perspectives and definitions.

Insert Table 1 about here

Such diversity of definitions suggests that gossip can span from an all-encompassing generic term concerning the exchange of social information and knowledge to a more precise term relating to evaluative talk between at least two persons about an absent third party. Additionally, the literature also indicates that there are different types of gossip, variously described as critical and uncritical (Taylor, 1994), information sharing and judgemental (Hannerz, 1967), positive and negative (Fine \& Rosnow, 1978; Leaper \& Holliday, 1995), blame or praise gossip (Soeters \& van Iterson, 2002) or good gossip and bad gossip (Bergmann, 1993; Goodman \& Ben-Ze'ev, 1994; Merry, 1984). Therefore, Ben-Ze'ev (1994, p. 12) suggests gossip is best seen as a prototypical cognitive category, with 'no clear and definite boundaries', and while there is no simple way of defining and describing all instances, there are nevertheless typical examples, and identifiable forms of gossip. This is 
RUNNING HEAD: Michelson, van Iterson, Waddington / Gossip in Organizations

consistent with our earlier call for flexibility, by which we mean that agreement should be reached in a general way among scholars as to what are the core elements of gossip so that some accumulation of research findings can occur across studies. Having identified such minimum criteria - for example, evaluative talk (written or spoken) between at least two persons about an absent third person(s), it is then necessary to think about offering more precision when studying gossip in different contexts and from whose perspective - the researcher's or the organizational member, work group and so on.

\section{Methodological Issues}

If the general experience of social scientists who draw extensively on qualitative techniques (broadly defined) is anything to go by, then it could be suggested that the widespread use of semi-structured interviews in management and organizational research is one way to capture relevant gossip (even if this outcome is not premeditated). The periodic request by interviewees to the researcher to 'turn off the (tape) recorder' might be a case in point to indicate some conscious tendency to report gossip. A pertinent question to pose could be: how often do scholars ignore such comments as irrelevant side issues, or do such off-therecord remarks provide important insights or clues which can then generate further lines of inquiry? Our point is that if some management and organizational researchers are periodically prepared to allow such details to inform their particular studies, how should researchers who are explicitly interested in capturing the meanings and processes of gossip in an organization approach their investigations?

This question involves trying to make public what is an essentially private talk. The relevant methodological characteristics might include the ethics of 'eavesdropping' (see Kniffin \& Wilson, this volume, for their discussion about third parties hearing the gossip) and 
RUNNING HEAD: Michelson, van Iterson, Waddington / Gossip in Organizations

other covert data collection methods (see Noon, 2001). Confidential 'gossipy' conversations may be private amongst work colleagues and friends, but secret to enemies, non-allies and researchers. Securing the consent of informants for their participation in a study on gossip might be difficult when one is seeking to create a more naturalistic setting vis-à-vis a participant-observation study (Michelson \& Mouly, 2002). In such scenarios, the researcher becomes part of the situation in which they are investigating and covert and non-consensual research, while not normally condoned by University ethics committees, could nonetheless still be possible in exceptional cases. One such case, as argued by Marzano, is the study of gossip (see Marzano, 2007, p. 422).

In addition to participant observation as a possibility for future studies, diaries also provide an excellent opportunity for organizational members to record - soon after the gossip exchange - their contributions and reactions to the exchange (see Waddington, 2005), which then might be used by the researcher. However, such techniques are seldom adopted but would allow for further investigation of gossip over the longer term. Of course, we are alert to the possibility that organizational members could censure their own diary entries, but this in itself would be insufficient reason a priori to not consider using such techniques. The articles in this Special Issue bear testament to some other methodological possibilities - social network analysis and the employment of quantitative tools, secondary analysis of published data, and a sensemaking perspective of managers and employees for the collection of qualitative data.

It is therefore clear that a variety of methodological approaches to help study gossip in organizations is possible and, we would argue, should be employed. The beginning and end points of gossip are not easily identified since gossip can be temporarily forgotten but then resurface within the same or even a different context at a future date. To investigate such complex and recurring patterns across both time and within different organizational spaces 
RUNNING HEAD: Michelson, van Iterson, Waddington / Gossip in Organizations

requires openness to a variety of methodological techniques which allows for longitudinal data to be collected. Given the proliferation of different technologies including email, mobile telephone texting, Facebook and other electronic bulletin boards, the task of collecting relevant data is increasingly possible. Relatedly, it would be interesting to evaluate the extent to which these technologies complement face-to-face gossip or substitute for it. There are very few studies in this area (for an exception, see Lee Harrington \& Bielby, 1995), but arguably research into the consequences of social networking sites (SNSs) such as Facebook is necessary because such sites duplicate many of the functions of gossip as a form of 'social grooming' (Dunbar, 1996). Seen in this sense, gossip establishes and maintains relationships and is a way of understanding alliances and hierarchies. Similarly, users of SNSs display their own profiles, networks of 'friends' and observe the profiles of others, presenting a public self for their community. As Tufecki (2008) notes, status verification, relationship confirmation and mutual acknowledgement are publicly displayed features of SNSs.

\section{Ethical Issues}

It could be argued that one reason why gossip has hitherto attracted limited attention in management and organizational studies (noted earlier) is because of the pejorative labelling of gossip as a morally suspect activity. If this idea is supported, it might suggest that gossip is one of a number of 'tainted topics' in organizational behavior (see MacLean, Anteby, Hudson \& Rudolph, 2006).

Gossip is still generally discredited or condemned in the public domain as being corrosive and pejorative talk, certainly where it is considered 'excessive' or 'inappropriate' (which is determined according to the specific setting and participants). Yet the reality is that there is widespread interest and participation in gossip. Thus, there is a discrepancy between 
RUNNING HEAD: Michelson, van Iterson, Waddington / Gossip in Organizations

the collective public condemnation and the collective private practising of gossip (Bergmann, 1993, p. 21). Foster (2004, p. 79) refers to this as 'the paradox of gossip'; it is widespread, yet there appears to be numerous social sanctions against it. Whether the valence of this sanction is still high remains to be seen. One could postulate that the widespread participation in social networking sites (SNSs) could, in general terms, begin to weaken this sanction. Juxtaposed against this is an associated reputation of trivial, superficial and idle talk. This leads to a second paradox in the everyday 'common sense' understandings of gossip, and begs the following questions: '[I]f gossip really is so unimportant, trivial, vacuous and idle, whence comes its dangerous qualities? Why is gossip so threatening and why should it be so violently condemned?' (Emler, 1994, p. 118).

As widely-practiced talk, it seems that gossip in organizations is underpinned by moral and ethical considerations as reflected in such opening statements as 'I don't like to gossip but...' or 'You haven't heard this from me...'. In spite of apparent personal reservations that may have as their source numerous underlying reasons, the information is nonetheless still transmitted. The purpose of this section is to identify how ethical issues are indeed relevant when dealing with organizational gossip. For present purposes, the discussion is kept relatively brief and does not exhaust the full range of ethical possibilities. We turn to some of the reasons against allowing and, consequently, studying gossip, before canvassing some points in favour of gossip.

\section{Against Gossip}

Gossip has attracted criticism because of its general capacity (attributed to underlying intention or motive) to generate a range of negative outcomes including disharmony, suspicions and seeing the worst in other people. Through gossip, people seem particularly pleased to discover and discuss the faults and weaknesses of others. There seems a 
RUNNING HEAD: Michelson, van Iterson, Waddington / Gossip in Organizations

schadenfreude or pleasure (if many of us are honest) in pointing out the existence of misfortune, error or wrong-doing in others. To give vent to that pleasure is one of the functions of gossip. Thus, utilitarian arguments based on a range of actual and potential harmful consequences are not uncommon when discussing the case against gossip. Such concerns might be raised both about the content of the gossip and its impact on persons (the target of the gossip).

The distinction between actions and persons is difficult to separate when it comes to gossip (Bergmann, 1993, p. 121). For example, a derogatory comment about a particular style of suit or dress worn by an absent colleague is essentially a comment about that person's (poor) taste. The action itself (the wearing of 'that' suit or dress) is not morally problematic but the translation of this action to a negative evaluation made by colleagues about the other person is what would be called into question by those against gossip. Shaping the opinion of organizational members through gossip might therefore create a culture of censure that potentially interferes with that individual's freedom, a point on which the philosopher, John Stuart Mill, would certainly oppose.

For those who engage in gossip (the gossiper and his or her audience) the action of gossip itself purportedly can strengthen relationships and trust (see below). However, for persons who are the targets of gossip the act and content of gossip may damage relationships and serve to perpetuate their sense of being an outsider (see Elias \& Scotson, 1994; Soeters \& van Iterson, 2002). The question then arises: does the moral objection against gossip lessen if the subject or target of the gossip is blissfully unaware of the gossip about them? In other words, the direct harm against the target in this situation would be negligible. But reference to another philosophical perspective would still lead to the same conclusion against gossip. In Kantian terms, one might ask whether you would wish to be treated in the same manner, 
RUNNING HEAD: Michelson, van Iterson, Waddington / Gossip in Organizations

whether you are treating the subject of gossip with respect, and whether you are using that person simply as a means of enhancing one's own pleasure.

On the point of pleasure, Holland (1996) argues that those factors from which persons derive pleasure, both forms and reveals their character. If gossip is precipitated principally by suspect or sinister motives towards other people then gossip might not merely harm the target of gossip itself but also the gossiper. That is, evaluative talk about other persons might point to and perpetuate flaws such as low self-esteem and self-respect in the gossiper's own character. By concentrating on the ostensible shortcomings and faults of others might, in some cases, be an attempt to deflect or divert attention from one's own limitations or inadequacies. Moreover, to concentrate on the faults of others is also an attempt to present oneself in a favourable light (Bergmann, 1993, p. 128); the focus on other persons tends to imply that the gossiper does not suffer from these faults. However, some care must be taken since the transmission of gossip is not always triggered by the pursuit of pleasure. The level of anxiety experienced by a person, for example, has been found to predict the transmission of gossip (Jaeger et al. 1998).

\section{In Defence of Gossip}

In addition to those moral philosophers who countenance against gossip, there are also scholars from within the philosophical tradition who adopt a more optimistic view towards gossip. Since gossip entails the exclusion of some persons (the targets of gossip) it can be regarded quite literally as behind-the-back talk (spoken or written) about others. At face value this might appear to contravene the wider moral rule about the treatment of other people: 'Do to others as you would have them do to you' which is endorsed by Kantian philosophy. But talking behind-the-back is not necessarily synonymous with a stab-in-the-back. The latter would assume that all such communication is negative and motivated by the intent to harm 
RUNNING HEAD: Michelson, van Iterson, Waddington / Gossip in Organizations

others. This is not always the case. For instance, if a supervisor tells an employee how they could improve their promotion opportunities with the manager (absent third party), this poses no problem when the manager is not opposed to such knowledge being known.

Building on this illustration, there are many cogent arguments put forward to justify gossip, or at least some gossip. For example, it has previously been suggested that gossip is an inherently democratic process, acting as a resource for moral understanding and freedom of speech (de Souza, 1994). Seen in this way, gossip can express perceptions of transgression or wrongdoing in different social situations (Sabini \& Silver, 1982, p. 105). Similarly, BenZe'ev (1994) contends that the prohibition of gossip on ethical grounds is not necessarily justified because such prohibition focuses on extreme, non-typical cases, and simply serves to reinforce the negative stereotypes, perception and reputation of gossip. Such reinforcement promotes distortion and misunderstanding, and the positive functions of gossip, including its intrinsic value as an activity that is easygoing and enjoyable, are often ignored. Thus, the issue may have far less to do with the content of gossip as a common objection noted by opponents of gossip, but one of recognizing the value of gossip as a means by which people learn to relate well to one another.

The proposition that gossip is primarily about relating and relationships rather than content is of interest. It could assume that what is actually discussed is largely immaterial to the wider purpose of enhancing social bonds between the participants. Since gossip is evaluative talk, value judgments are nonetheless made about content during the process of establishing and building relationship. This is not to suggest that the content is unimportant; simply, that the topics of gossip are not the primary objective of the talk between the gossiper and listener/respondent. The relationship between the gossip participants and the persons who are the targets of gossip is a different matter and was addressed earlier. 
RUNNING HEAD: Michelson, van Iterson, Waddington / Gossip in Organizations

It could also be the case that the view of gossip as a moral problem is flawed by misrepresentation of the potential to harm. To illustrate this point, Ben-Ze'ev (1994) draws an analogy for gossip with eating. While excessive eating is harmful, this does not imply an intrinsic evil in eating. Similarly, if we accept that excessive and distorted gossip can potentially also be harmful, this does not establish or validate the intrinsic malicious nature of every piece of gossip. Take, for instance, one employee who notes to an approving co-worker about another colleague, 'I am so pleased to hear about Lisa's new baby'.

In sum, there is no doubt that at a more universal level of understanding gossip enjoys a poor reputation and has been subject to widespread and enduring disapproval and censure. Such objections are often centred on the rights and freedoms of the gossip target. From the perspective of the gossiper and listener/respondent, the arguments against gossip appear less certain. To suggest that all gossip is harmful is not a position that can be easily accepted as we need to appreciate that different relationships exist between the three main groups (gossiper, listener/respondent and target). However, to also suggest that our position is that gossip is regarded as entirely virtuous would also be misleading. To be sure, some gossip can indeed be morally problematic in organizational settings. But, equally, there are instances when some gossip should not be condemned (see Westacott, 2000).

\section{CONCLUSION}

This article has highlighted the significance of gossip in organizations as an activity that is of widespread and general relevance to a broad range of management and organization scholars. Often taken to mean evaluative talk (written or spoken) between at least two persons about an absent third person(s), it has application across many different organizational settings such as healthcare, education, business, and public, private and voluntary/community sectors. Gossip 
RUNNING HEAD: Michelson, van Iterson, Waddington / Gossip in Organizations

is also amenable to different theoretical and methodological perspectives. For example, there is scope for collaborative research to be done through the eyes (and ears) of participants as coresearchers. In addition to the definitional and methodological challenges, the article also examined ethical arguments for and against gossip, and its study. It was shown that such concerns are more problematic in the case of the gossip target, than for the gossiper and the listener/respondent groups. The three challenges and controversies were therefore raised in the hope that they might more clearly inform and guide future researchers in the study of organizational gossip.

It is evident that gossip as a social and organizational phenomenon has gained some credibility as a topic of research interest and academic debate in the social science disciplines in general. However, we argue it still has some progress to make within management and organizational studies. By positioning gossip as a central, rather than peripheral or coincidental behavior, this, and the other articles in the Special Issue, aims to make a contribution to this growing literature. Collectively, the theoretical and empirical studies presented here add to the intellectual reputation and rehabilitation of gossip as a phenomenon worthy of further research and scholarship in management and organizations. 
RUNNING HEAD: Michelson, van Iterson, Waddington / Gossip in Organizations

\section{REFERENCES}

Akande, A., \& Funmilayo, O. (1994). One more time - how to stop company rumours. Leadership and Organization Development Journal, 15, 27-30.

Ayim. M. (1994) Knowledge through the grapevine: Gossip as inquiry. In In R.F. Goodman \& A. Ben-Ze'ev (Eds.), Good gossip (pp. 85-99). Kansas: University Press of Kansas.

Baker, J.S., \& Jones, M.A. (1996). The poison grapevine: How destructive are gossip and rumor in the workplace. Human Resource Development Quarterly, 7, 75-86.

Baumeister, R.F., Zhang, L., \& Vohs, K.D. (2004). Gossip as cultural learning. Review of General Psychology, 8, 111-121.

Ben-Ze'ev, A. (1994). The vindication of gossip. In R.F. Goodman \& A. Ben-Ze'ev (Eds.), Good gossip (pp. 11-24). Kansas: University Press of Kansas.

Berger, C.R. (2005). Interpersonal communication: Theoretical perspectives, future prospects. Journal of Communication, 55, 415-447.

Bergmann, J.R.(1993). Discreet indiscretions: The social organization of gossip. New York: Aldine de Gruyter.

Boje, D.M. (1991). The storytelling organization: A study of story performance in an office supply firm. Administrative Science Quarterly, 36, 106-126.

Bordia, P., Jones, E., Gallois, C., Callan, V.J. \& DiFonzo, N. (2006). Management are aliens! Rumors and stress during organizational change. Group \& Organization Management, $31,601-621$.

Brass, D.J., Galaskiewicz, J., Greve, H.R., \& Tsai W. (2004). Taking stock of networks and organizations: A multilevel perspective. Academy of Management Journal, 47, 795817. 
RUNNING HEAD: Michelson, van Iterson, Waddington / Gossip in Organizations

Burke, L.A., \& Wise, J.M. (2003). The effective care, handling, and pruning of the office grapevine. Business Horizons, 46, 71-76.

Burt, R.S., \& Knez, M. (1996). Trust and third party gossip. In R.M. Kramer \& T.R. Tyler (Eds.), Trust in organizations: Frontiers of theory and research (pp. 68-89). Thousand Oaks, CA: Sage.

Davis, K. (1953a). Management communication and the grapevine. Harvard Business Review, $31,43-49$.

Davis, K. (1953b). A method of studying communication patterns in organizations. Personnel Psychology, 6, 301-312.

Davis, K. (1969). Grapevine communication among lower and middle managers. Personnel Journal, 48, 269-272.

Davis, K. (1973). The care and cultivation of the corporate grapevine. Management Review, $62,308-315$.

de Souza, R. (1994). In praise of gossip. In R.F. Goodman \& A. Ben-Ze'ev (Eds.), Good gossip (pp. 25-33). Kansas: University Press of Kansas.

DiFonzo, N. \& Bordia, P. (2007). Rumor psychology: Social and organizational approaches. Washington, DC: American Psychological Association.

DiFonzo, N., Bordia, P, \& Rosnow, R. (1994). Reigning in rumors. Organizational Dynamics, 23, 47-62.

Doyle, J. (2000). New community or new slavery? The emotional division of labour. London: The Industrial Society.

Dunbar, R. (1996). Grooming, gossip and the evolution of language. London: Faber \& Faber.

Dunbar, R. (2004). Gossip in evolutionary perspective. Review of General Psychology, 8, 100-110. 
RUNNING HEAD: Michelson, van Iterson, Waddington / Gossip in Organizations

Eder, D., \& Enke, J.L. (1991). The structure of gossip: Opportunities and constraints on collective expression among adolescents. American Sociological Review, 56, 494-508.

Elias, N. \& Scotson, J. (1994). The established and the outsiders: A sociological inquiry into community problems (revised edition). London: Sage.

Emler, N. (1994). Gossip, reputation, and social adaptation. In R.F. Goodman \& A. BenZe'ev (Eds.), Good gossip (pp. 117-138). Kansas: University Press of Kansas.

Festinger, L. (1957). A theory of cognitive dissonance. Evanston, IL: Row, Peterson \& Co.

Fine, G., \& Rosnow, R. (1978). Gossip, gossipers, gossiping. Personality and Social Psychology Bulletin, 4, 161-168.

Foster, E.K. (2004). Research on gossip: Taxonomy, methods and future directions. Review of General Psychology, 8, 78-99.

Fox, K. (2001). Evolution, alienation and gossip. Oxford: Social Issues Research Centre.

Gabriel, Y. (1991). Turning facts into stories and stories into facts: A hermeneutic exploration or organizational folklore. Human Relations, 44, 857-875.

Gabriel, Y. (1995). The unmanaged organization: Stories, fantasies and subjectivity. Organization Studies, 16, 477-501.

Gabriel, Y. (2000). Storytelling in organizations: Facts, fictions and fantasies. Oxford: Oxford University Press.

Gabriel, Y., Fineman, S., \& Sims, D. (2000). Organizing and organizations. London: Sage.

Gluckman, M. (1963). Gossip and scandal. Current Anthropology, 4, 307-316.

Goodman, R.F., \& Ben-Ze'ev, A. (Eds.) (1994). Good gossip. Kansas: University Press of Kansas.

Guerin, B., \& Miyazaki, Y. (2006). Analyzing rumors, gossip and urban legends through their conversational properties. Psychological Record, 56, 23-34. 
RUNNING HEAD: Michelson, van Iterson, Waddington / Gossip in Organizations

Hannerz, U. (1967). Gossip, networks and culture in a Black American ghetto. Ethnos, 32, 3560.

Heider, F. (1958). The psychology of interpersonal relations. New York: John Wiley \& Sons. Holland, M.G. (1996). What's wrong with telling the truth? An analysis of gossip. American Philosophical Quarterly, 33, 197-209.

Jaeger, M.E., Skleder, A.A. \& Rosnow, R. (1998). Who's up on the low down? Gossip in interpersonal relationships. In B.H. Spitzberg \& W.R Cupach (Eds.), The dark side of close relationships (pp. 103-117). Mahwah, NJ: Erlbaum.

Jones, D. (1980). Gossip: Notes on women's oral culture. Women's Studies International Quarterly, 3, 193-198.

Jones, E., Watson, B., Gardner, B., \& Gallois, C. (2004). Organizational communication: Challenges for the new century. Journal of Communication, 54, 722-750.

Karathanos, P., \& Auriemmo, A. (1999). Care and feeding of the organizational grapevine. Industrial Management, 41, 26-30.

King, E.B., Reilly, C., \& Hebl, M. (2008). The best of times, the worst of times: Exploring dual perspectives of 'coming out' in the workplace. Group \& Organization Management, 33, 566-601.

Kolb, D.M., \& Putnam, L.L (1992). The multiple faces of conflict in organizations. Journal of Organizational Behaviour, 13, 311-324.

Kniffin, K.M. \& Wilson, D.S. (2005). Utilities of gossip across organizational levels: Multilevel selection, free-riders, and teams. Human Nature, 16, 278-292.

Kurland, N.B., \& Pelled, L.H. (2000). Passing the word: Toward a model of gossip and power in the workplace. Academy of Management Review, 25, 428-438.

Leaper, C., \& Holliday, H. (1995). Gossip in same-gender and cross-gender friends' conversations. Personal Relationships, 2, 237-46. 
RUNNING HEAD: Michelson, van Iterson, Waddington / Gossip in Organizations

Lee Harrington, C., \& Bielby, D.D. (1995). Where did you hear that? Technology and the social organization of gossip. The Sociological Quarterly, 36, 607-628.

MacLean, T., Anteby, M., Hudson, B., \& Rudolph, J.W. (2006). Talking tainted topics: Insights and ideas on researching socially disapproved organizational behaviour. Journal of Management Inquiry, 15, 59-68.

Marzano, M. (2007). Informed consent, deception, and research freedom in qualitative research. Qualitative Inquiry, 13, 417-436.

McAndrew, F.T. \& Milenkovic, M.A. (2002). Of tabloids and family secrets: The evolutionary psychology of gossip. Journal of Applied Social Psychology, 32, 10641082.

McAndrew, F.T., Bell, E.K., \& Garcia C.M. (2007). Who do we tell and whom do we tell on? Gossip as a strategy for status enhancement. Journal of Applied Social Psychology, 37, $1562-1577$.

McClelland, D.C. (1987). Human motivation. Cambridge: Cambridge University Press.

Merry, S.E. (1984). Rethinking gossip and scandal. In D. Black (Ed.), Towards a general theory of social control, volume 1 fundamentals (pp. 271-301). Orlando: Academic Press.

Michelson, G., \& Mouly, S. (2000). Rumour and gossip in organisations: A conceptual overview. Management Decision, 38, 339-346.

Michelson, G., \& Mouly, S. (2002). 'You didn't hear it from us but...': towards an understanding of rumour and gossip in organisations. Australian Journal of Management, 27, 57-65.

Michelson, G., \& Mouly, S. (2004). Do loose lips sink ships? The meaning, antecedents and consequences of rumour and gossip in organisations. Corporate Communications, 9 , 189-201. 
RUNNING HEAD: Michelson, van Iterson, Waddington / Gossip in Organizations

Mishra, J. (1990). Managing the grapevine. Public Personnel Management, 19, 213-228.

Nevo, O., Nevo, B., \& Derech-Zehavi, A. (1993). Gossip and counselling: The tendency to gossip and its relation to vocational interest. Counselling Psychology Quarterly, 6, 229-238.

Nicholson, N. (2000). Managing the human animal. London: Texere.

Nicholson, N. (2001). The new word on gossip. Psychology Today, 34, 40-45.

Noon, M. (2001). Suggested revisions to Kurland and Pelled's model of gossip and power. Academy of Management Review, 26, 173-174.

Noon, M., \& Delbridge, R. (1993). News from behind my hand: Gossip in organizations. Organization Studies, 14, 23-36.

Ogasawara, Y. (1998) Office ladies and salaried men: Power, gender, and work in Japanese Companies. Berkeley, CA: University of California Press.

Paine, R. (1967). What is gossip about? An alternate hypothesis. Man, 2, 278-285.

Pierce, C.A., Byrne, D., \& Aguinis, H. (1996). Attraction in organizations: A model of workplace romance. Journal of Organizational Behavior, 17, 5-32.

Rosnow, R.L. (1977). Gossip and marketplace psychology. Journal of Communication, 27, 158-163.

Rosnow, R.L., Esposito, J.L., \& Gibney, L. (1988). Factors influencing rumor spreading, replication and extension. Language and Communication, 8, 29-42.

Rosnow, R.L., \& Fine, G.A. (1976). Rumor and gossip: The social psychology of hearsay. New York: Elsevier.

Sabini, J., \& Silver, M. (1982). Moralities of everyday life. New York: Oxford University Press. 
RUNNING HEAD: Michelson, van Iterson, Waddington / Gossip in Organizations

Soeters, J., \& van Iterson, A. (2002). Blame and praise gossip in organizations: Established, outsiders and the civilising process. In A. van Iterson, W. Mastenbroek, T. Newton, and D. Smith (Eds.), The civilised organization: Norbert Elias and the future of organization studies (pp. 25-40). Amsterdam/ Philadelphia: John Benjamins.

Suls, J.M. (1977). Gossip as social comparison. Journal of Communication, 27, 164-168.

Taylor, G. (1994). Gossip as moral talk. In R.F. Goodman, \& A. Ben-Ze’ev (Eds.), Good gossip (pp. 34-46). Kansas: University Press of Kansas.

Tebbutt, M., \& Marchington, M. (1997). 'Look before you speak': Gossip and the insecure workplace. Work, Employment \& Society, 11, 713-735.

Therrien, D. (2004). Rid your office of back-stabbers. Canadian Business, 77, 109-110.

Tufecki, Z. (2008). Grooming, gossip, Facebook and Myspace. Information, Communication \& Society, 11, 544-564.

van Iterson, A., \& Clegg, S. (2008) The politics of gossip and denial in interorganizational relations. Human Relations, 61, 1117-1137.

Waddington. K. (2005). Using diaries to explore the characteristics of work-related gossip: methodological considerations from exploratory, multimethod research. Journal of Occupational and Organizational Psychology, 78, 221-236.

Waddington, K., \& Michelson, G. (forthcoming). Gossip and organizations. London: Routledge.

Wert, S.R., \& Salovey, P. (2004). A social comparison account of gossip. Review of General Psychology, 8, 122-137.

Westacott, E. (2000). The ethics of gossiping. International Journal of Applied Philosophy, $14,65-90$. 
RUNNING HEAD: Michelson, van Iterson, Waddington / Gossip in Organizations

Zamanou, S., \& Glaser, S. (1994). Moving towards participation and involvement: Managing and measuring organizational culture. Group and Organization Management, 19, 475502.

Grant Michelson (gmichelson@audencia.com) is professor of management and director of research at Audencia Nantes School of Management, France. His research focuses on organizational change and gossip, business ethics, and well-being at work. He received his $\mathrm{PhD}$ in industrial relations and management at the University of Sydney.

Ad van Iterson (a.vaniterson@maastrichtuniversity.nl) is an associate professor of organization studies at Maastricht University, The Netherlands. His interests include the informal organization (e.g., gossip, mockery, narratives, impression management) and neoinstitutionalism. He earned his $\mathrm{PhD}$ in sociology from the University of Amsterdam.

Kathryn Waddington (k.waddington@city.ac.uk) is senior lecturer in Interdisciplinary Studies in Professional Practice at City University London, United Kingdom. Her primary research interests include the role of emotion at work, how gossip can inform political awareness within organizations, and leadership in the nursing and health care sector. She received her $\mathrm{PhD}$ in psychology from the University of London. 
RUNNING HEAD: Michelson, van Iterson, Waddington / Gossip in Organizations

Table 1: GossipDefinitions over Time

\begin{tabular}{|c|c|c|}
\hline Definition of Gossip & Source & Comment \\
\hline $\begin{array}{l}\text { Informal communication, a } \\
\text { device which serves to } \\
\text { protect individual interests }\end{array}$ & Paine (1967) & $\begin{array}{l}\text { Anthropological } \\
\text { perspective, individual } \\
\text { rather than social function }\end{array}$ \\
\hline $\begin{array}{l}\text { News about the affairs of } \\
\text { others, or one's own, or any } \\
\text { hearsay of a personal nature }\end{array}$ & Fine \& Rosnow (1978) & $\begin{array}{l}\text { Social psychology } \\
\text { perspective, includes } \\
\text { reference to self-disclosure }\end{array}$ \\
\hline $\begin{array}{l}\text { Evaluative talk about a } \\
\text { person who is not present }\end{array}$ & Eder \& Enke (1991) & $\begin{array}{l}\text { Sociological perspective } \\
\text { with narrow parameters }\end{array}$ \\
\hline $\begin{array}{l}\text { Verbal and written } \\
\text { communication, no obvious } \\
\text { conscious purpose } \\
\text { regarding the personal } \\
\text { matters of a third party }\end{array}$ & Nevo et al. (1993) & $\begin{array}{l}\text { Psychological perspective, } \\
\text { gossip as social action }\end{array}$ \\
\hline $\begin{array}{l}\text { Talk between two or more } \\
\text { persons about the private } \\
\text { life of another behind that } \\
\text { person's back }\end{array}$ & Taylor (1994) & $\begin{array}{l}\text { Emphasizes the secretive } \\
\text { and potentially harmful } \\
\text { nature of gossip }\end{array}$ \\
\hline $\begin{array}{l}\text { Idle relaxing activity, value } \\
\text { lies in the activity itself, not } \\
\text { the outcome }\end{array}$ & Ben-Ze'ev (1994) & $\begin{array}{l}\text { Philosophical perspective, } \\
\text { emphasis upon process } \\
\text { rather than outcome }\end{array}$ \\
\hline $\begin{array}{l}\text { The exchange of } \\
\text { information about other } \\
\text { people/social matters }\end{array}$ & Dunbar $(1996 ; 2004)$ & $\begin{array}{l}\text { Evolutionary psychology } \\
\text { perspective, broad } \\
\text { parameters }\end{array}$ \\
\hline $\begin{array}{l}\text { Informal communication } \\
\text { transmitted to others } \\
\text { irrespective of whether or } \\
\text { not the content is factual }\end{array}$ & Michelson \& Mouly (2000) & $\begin{array}{l}\text { Conceptual study which } \\
\text { uses gossip and rumor } \\
\text { interchangeably }\end{array}$ \\
\hline $\begin{array}{l}\text { The act of sharing stories } \\
\text { with others }\end{array}$ & Gabriel et al. (2000) & $\begin{array}{l}\text { Focus upon organizational } \\
\text { gossip and storytelling }\end{array}$ \\
\hline $\begin{array}{l}\text { Exchange of personal } \\
\text { information in an evaluative } \\
\text { way about absent third } \\
\text { parties }\end{array}$ & Foster (2004) & $\begin{array}{l}\text { Inclusive definition set in a } \\
\text { context of congeniality, } \\
\text { including both positive and } \\
\text { negative aspects }\end{array}$ \\
\hline $\begin{array}{l}\text { Evaluative social talk about } \\
\text { persons, usually not present, } \\
\text { arising in the context of } \\
\text { social networks }\end{array}$ & DiFonzo \& Bordia (2007) & $\begin{array}{l}\text { Social network perspective, } \\
\text { essential functions relate to } \\
\text { entertainment, group } \\
\text { membership, solidarity, } \\
\text { norms and power structure }\end{array}$ \\
\hline $\begin{array}{l}\text { Evaluative talk between at } \\
\text { least two persons that may } \\
\text { be spoken (most common), } \\
\text { written (less common), or } \\
\text { visual }\end{array}$ & $\begin{array}{l}\text { Waddington \& Michelson } \\
\text { (forthcoming) }\end{array}$ & $\begin{array}{l}\text { Multi-perspective approach, } \\
\text { draws attention to non- } \\
\text { verbal aspects of gossip }\end{array}$ \\
\hline
\end{tabular}

